\title{
Unexpected patterns of genetic connectivity in Lobophyllia corymbosa (Forskål, 1775) around Sulawesi, Indonesia
}

\author{
WIDYASTUTI UMAR ${ }^{1, \vartheta}$, ASMI CITRA MALINA A.R. TASSAKKA ${ }^{1}$, PAUL H. BARBER ${ }^{2}$, \\ JAMALUDDIN JOMPA ${ }^{3, \vee v}$ \\ ${ }^{1}$ Faculty of Marine Science and Fisheries, Universitas Hasanuddin. Jl. Perintis Kemerdekaan Km. 10, Tamalanrea, Makassar 90245, South Sulawesi, \\ Indonesia. Tel./fax.: +61-411-586025, ^email: widyastuti160@gmail.com \\ ${ }^{2}$ Department of Ecology and Evolutionary Biology, University of California Los Angeles. 90095, Los Angeles, CA, USA \\ ${ }^{3}$ Center of Marine Resilience and Sustainable Development, Universitas Hasanuddin. Jl. Perintis Kemerdekaan Km. 10, Tamalanrea, Makassar 90245, \\ South Sulawesi, Indonesia. ^»email: j.jompa@unhas.ac.id
}

Manuscript received: 15 August 2019. Revision accepted: 29 August 2019.

\begin{abstract}
Umar W, Tassakka ACMAR, Barber PH, Jompa J. 2019. Unexpected patterns of genetic connectivity in Lobophyllia corymbosa (Forskål, 1775) around Sulawesi, Indonesia. Biodiversitas 20: 2744-2749. Sulawesi is a strategic area for the biological networks of marine organisms, especially for Scleractinian corals. Sulawesi is located centrally in Indonesia and influenced by Pacific and Indian Ocean currents and shown in unique biodiversity patterns. However, research in this region is very limited. The wide distribution and lack of information on dispersal and connectivity make Lobophyllia corymbosa an exciting candidate in this study for genetic connectivity at the heart of the Indonesian Coral Triangle Area (ICTA), using Mitochondrial DNA (mtDNA) genome. Sampling sites (Palu, Mamuju, Sinjai, and Luwuk Banggai) with different coral fragments were collected from each site, DNA extracted, and mitochondrial COI gene was amplified. The results of the analysis were unexpected, and we hypothesise that the observed pattern was due to the evolution of different lineages within this region. The distance index and genetic diversity showed a close relationship between Mamuju and Luwuk Banggai, while Sinjai and Palu had a different genetic pattern. The global current patterns, complicated geography, and habitat condition could lead to such an outcome. Hard coral larvae arriving in an area might bypass a number of possible "stepping stones", resulting in unique patterns and leading to unexpected genetic connections within and between areas.
\end{abstract}

Keywords: Connectivity patterns, genetic variation, mitochondrial, scleractinian coral, Sulawesi

\section{INTRODUCTION}

The Coral Triangle is the global epicentre of marine biodiversity and Indonesia is the heart of this region. Biodiversity in Indonesia reaches its highest at the very west part - Eastern Islands of West Papua, and its lowest at the east part - Western Islands of Java and Sumatra (Roberts et al. 2002; Bellwood and Meyer 2009). Between these two regions, lies a group of Islands of Sulawesi. Sulawesi formed through island integration over the last 5 million years and its western, eastern and shores experience very different oceanography. Western Sulawesi boarders the Indonesian Through Flow (ITF), the primary pathway for water transport from the Pacific to the Indian Ocean where currents can exceed $1 \mathrm{~m} / \mathrm{s}$, while the eastern shores border the Maluku and Banda Seas, where there is little north to south transport (Gordon and Fine 1996). Modelling of oceanographic currents in this region (Treml et al. 2012; Kool et al. 2013) suggests that these different current regimes should have a significant impact on larval dispersal.

Many studies have used genetics to infer patterns of larval dispersal within Indonesia (Barber et al. 2000, 2002, 2006; Timm et al. 2017; DeBoer and Barber 2010; Crandall et al. 2010). These studies typically identify three unique regions: (i) Western Indonesia, including Sumatera, and Java, (ii) Central Indonesia including the Lesser of Sunda
Islands, Sulawesi, and Sangihe-Talaud, and (iii) Eastern Indonesia, including Halmahera and West Papua (Barber et al. 2011; Carpenter et al. 2011). However, rarely these studies sampled on both sides of Sulawesi, and when they do, sampling has focused on the isolated islands in the Bay of Tomini.

The condition of coral reefs is declining worldwide, including Indonesia, and up to $85 \%$ of the damage occurring at the site is due to the anthropogenic activity (Burke et al. 2002). This degradation is concerning because of the economic and biological value of coral reefs (Cesar et al. 2003). Previous population genetic studies of corals in Indonesia have shown high levels of genetic differentiation, often on small spatial scales (Starger et al. 2010), suggesting that both genetic and demographic connectivity are limited (Hedgecock et al. 2007). As such, coral populations, the foundation of reef ecosystems, could be slow to recover from local disturbance. This fact is of particular interest in Sulawesi as the unique oceanographic regimes on its west and east coasts that could result in very different connectivity patterns around the island. However, to date, no coral studies have sampled on both sides of Sulawesi.

Lobophyllia corymbosa is a common coral around Sulawesi that traded as an ornamental coral. Although the International Union for Conservation of Nature (IUCN) lists this coral as a species Least Concern (Turak et al. 
2014), L. corymbosa is a broadcast spawner coral (Coexploration 2017), making it a good model for understanding variation in genetic connectivity around the island of Sulawesi. Besides, it is only has reported from Sulawesi, the Seribu Archipelago and West Nusa Tenggara, making Sulawesi the northernmost portion of the species range so that patterns around Sulawesi cannot be influenced by upstream larval transport. In this study, we expand the geographic sampling to cover the western and eastern shored and use mtDNA sequences, which have been particularly useful in coral studies (Vollmer and Palumbi 2007) to determine patterns of genetic differentiation and connectivity.

\section{MATERIALS AND METHODS}

\section{Sample collection}

Field sampling was conducted during February-March 2017 and March at 2018, and then in four locations around Sulawesi, we collected 20 fragments from Palu, 13 from Mamuju, 15 samples from Sinjai and also 15 from Luwuk Banggai. The sites were determined based on the geographical form of Sulawesi and its surrounding waters, as well as the lack of data on genetic connectivity in those areas (Figure 1). Samples (L. corymbosa fragments) from different colonies were collected at each site at an average depth of 3-7 meters using a hammer and chisel. Within each population (location), sampling was random, with a distance of at least 2-10 meters between colonies to

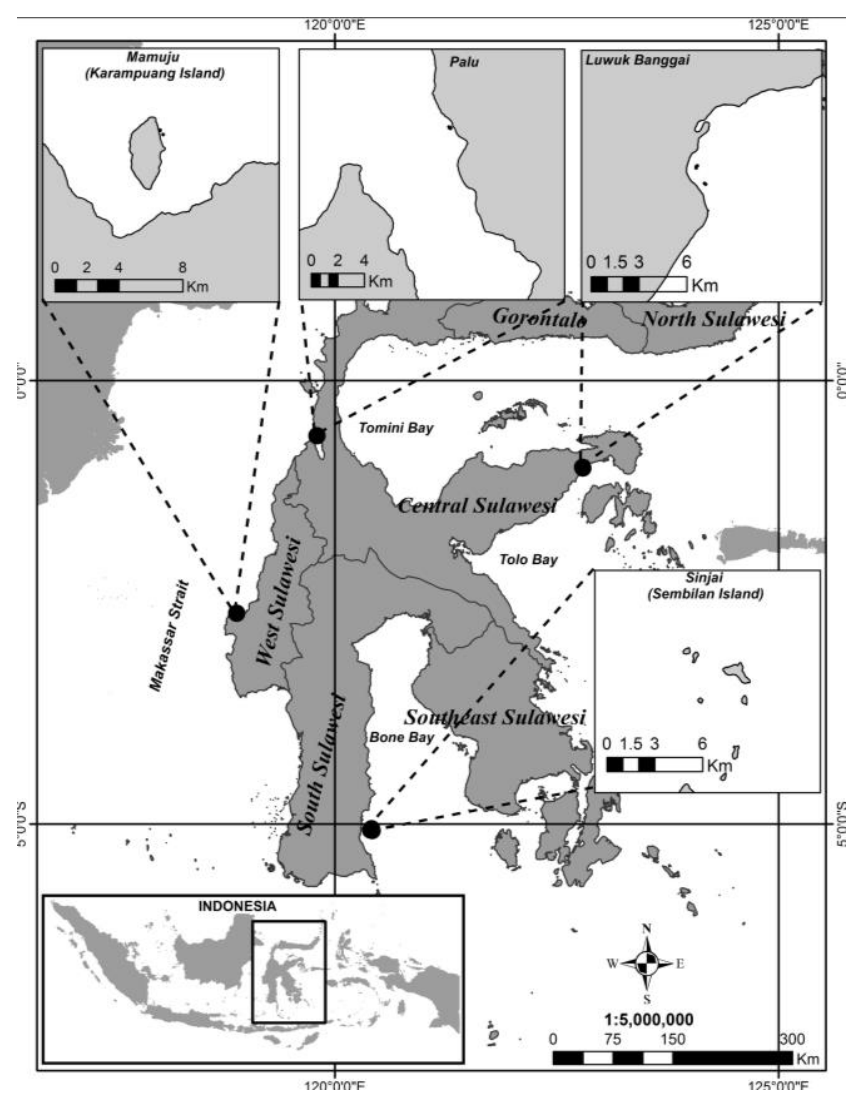

Figure 1. Map of research sites in Sulawesi waters, Indonesia minimise the likelihood of collecting clones (Van der Ven et al. 2016; Hemond and Vollmer 2010). After collection, the samples were preserved in $95 \%-100 \%$ laboratory grade ethanol in individually labelled containers and stored at room temperature for further analysis (Huang et al. 2011; Timm et al. 2017).

\section{Procedures}

Primer design and selection-1

Primer design and selection referred to accession number AB117241.1 in the NCBI Web (National Centre for Biotechnology Information). Specific mitochondrial Cytochrome Oxidase I (COI) primers were designed and tested using BLAST to ensure their suitability for the target samples. Potential primer selection aimed to find a suitable pair which could be amplified from the samples. The primer pair selected was: mtCOI CAGG CGCT ATGT TAGG AGATG as a forward and mtCOI CCCG CTAA TACA GGCA AAG ATA as a reverse. In this research, we used the mitochondrial genome as a target, because of ancestor information can be defined from that marker, from this, it will provide connectivity information that flows to an organism.

\section{DNA extraction, PCR, electrophoresis, and sequencing-2}

Genomic coral DNA was extracted using a commercial extraction kit (Qiagen Blood and Tissue Kit); procedures followed the protocols used in previous research (Huang et al. 2011). Coral tissue was retrieved by crushing the coral fragments to obtain a $0.10 \mathrm{~g}$ sub-sample from each sample. Following the protocol, the sub-samples were incubated in the Qiagen kit lysis solution in a heat block at $56^{\circ} \mathrm{C}$ for 24 hours (Van der Ven et al. 2016). The proprietary extraction processes (protocols) were then followed to obtain DNA genomic extracts, which were then stored in a freezer at $4^{\circ} \mathrm{C}$ (Cho and Shank 2010).

PCR was performed in $0.2 \mathrm{~mL}$ reaction tubes, using the MyTaq RedMix (Bioline) reagent mix. Each tube contained a volume of $26 \mu \mathrm{L}$ consisting of $10 \mu \mathrm{L}$ ddH2O, $1.25 \mu \mathrm{L}$ each of the forward and reverse primers, $12.75 \mu \mathrm{L}$ MyTaq RedMix (Bioline), and two $\mu \mathrm{L}$ of template DNA (Fukami et al. 2004). The thermocycler profile consisted of 38 cycles, preceded by a pre-denaturation at $95^{\circ} \mathrm{C}$ for $15 \mathrm{~min}$, with denaturation at $94^{\circ} \mathrm{C}$ for $1 \mathrm{~min}$, annealing at $53^{\circ} \mathrm{C}$ for $1 \mathrm{~min}$, and extending at $72^{\circ} \mathrm{C}$ for $105 \mathrm{~s}$, followed by a final stage at $72^{\circ} \mathrm{C}$ for $10 \mathrm{~min}$.

The presence or absence of a DNA band was determined through electrophoresis on an agarose bed $(1 \%$ agarose gel, $0.75 \mathrm{~g} ; 75 \mathrm{~mL}$ SB Buffer; $4 \mu \mathrm{L}$ Ethidium Bromide) at $100 \mathrm{~V} / 400 \mathrm{amp}$ for $30 \mathrm{~min}$. PCR products testing positive for DNA were then sent to the Sequencing Centre, Berkeley for Sanger sequencing (Kortschak et al. 2003). Sequences obtained were edited (to remove ambiguous bases at each end) and analysed in Molecular Evolutionary Genetic Analysis (MEGA) ver. 6 (Tamura et al. 2013), using the statistical method of Maximum Likelihood with 1000 bootstrap replicates (Tamura and Nei 1993) to infer the evolutionary relationships between the samples. The evolutionary distances were computed using the Kimura 2-parameter method (Kimura 1980) in units of 
a number of base substitutions per site. All positions were edited and eliminated for further analysis. Evolutionary analyses were conducted in MEGA 6 (Tamura et al. 2013) and haplotype diversity analysis was implemented in DnaSp ver. 5.10 (Librado and Rozas 2009).

\section{RESULTS AND DISCUSSION}

\section{Results}

The mitochondrial genomic material derived from each of the 64 nucleotide samples was successfully amplified and produced an informative sequencing product. The nucleotide base was trimmed with 437 base pairs (bp) in length. The sequences of all samples had a similarity of 99\%-100\% with the L. corymbosa sequence on Genebank with accession number AB117241 (Fukami et al. 2004).

The optimal phylogenic tree with the sum of branch length $=0.002$ (Figure 2) showed a pattern of two significant clusters formed from the four L. corymbosa populations (Palu-Sinjai and Mamuju-Luwuk Banggai). Genetic distance values obtained from distance method in pairwise difference. The values indicated that for connectivity, locally, they had a very close relationship. However, when comparing them with index D on intrapopulation, the unexpected happened to the population of Mamuju and Luwuk Banggai. Their genetic distance was 0.037, as well as the value formed in Sinjai and Palu population ranges from 0.010, which was not much different from the previous populations. While the genetic distance formed in geographically possible areas to have a close relationship with Palu, Mamuju, and Sinjai showed a $\mathrm{D}$ value that tended to be high (Table 1).

In addition to genetic distance analysis, the results of the haplotype diversity analysis showed the distribution of diversity and haplotypes within each population (Table 2). A total number of $11 \mathrm{~L}$. corymbosa haplotypes were identified, with a geographical distribution shown in Figure 3. Mamuju and Luwuk Banggai areas shared haplotypes (1 and 2), as did Palu and Sinjai that shared one significant haplotype in yellow one (haplotype 4). Mamuju and Palu, the two sites closest to each other, only shared one haplotype (7). Besides, one haplotype was only found in Luwuk Banggai (3), while Palu had three uniques haplotype $(9,10$, and 11) and neither in Mamuju with two specific haplotypes (6 and 8).

Table 1. The number of base substitutions per site from averaging over all sequence pairs between populations are shown in distance method of pairwise difference

\begin{tabular}{lcccc}
\hline Site & $\begin{array}{c}\text { Luwuk } \\
\text { Banggai }\end{array}$ & Sinjai & Mamuju & Palu \\
\hline Luwuk Banggai & & & & \\
Sinjai & 0.566 & & & \\
Mamuju & 0.037 & 0.577 & & \\
Palu & 0.604 & 0.010 & 0.603 & \\
& & & & \\
\hline
\end{tabular}

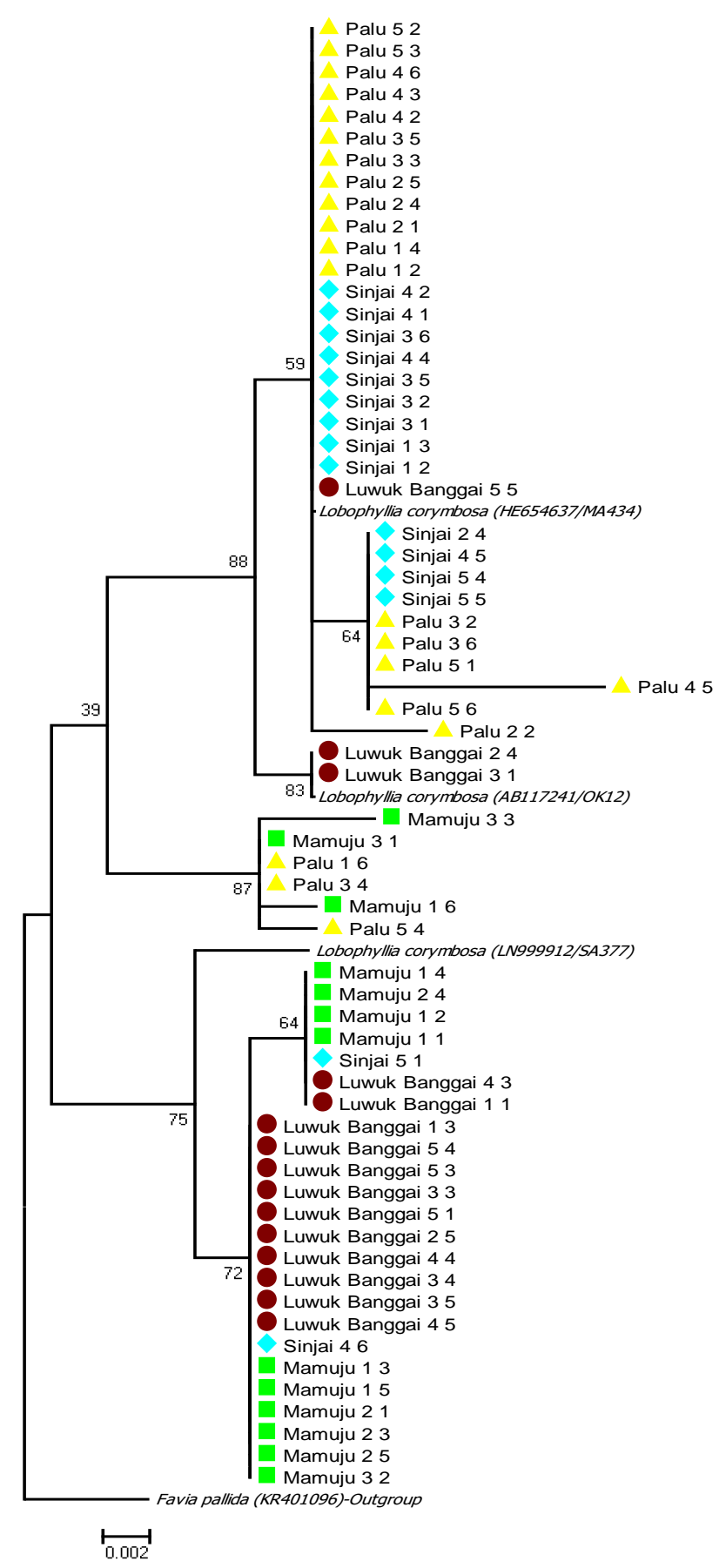

Figure. 2. Molecular Phylogenetic analysis by Maximum Likelihood method. The evolutionary history was inferred by using the Maximum Likelihood method based on the Tamura-Nei model (1993). The tree with the highest log likelihood (771.0636) is shown. The percentage of trees in which the associated taxa clustered together is shown next to the branches. Initial tree for the heuristic search were obtained by applying the Neighbor-Joining method to a matrix of pairwise distances estimated using the Maximum Composite Likelihood (MCL) approach. A discrete Gamma distribution was used to model evolutionary rate differences among sites (5 categories $(+\mathrm{G}$, parameter $=0.1000)$ ). The rate variation model allowed for some sites to be evolutionarily invariable $([+], 12.7630 \%$ sites $)$. The tree is drawn to scale, with branch lengths measured in the number of substitutions per site. Evolutionary analyses were conducted in MEGA6. 


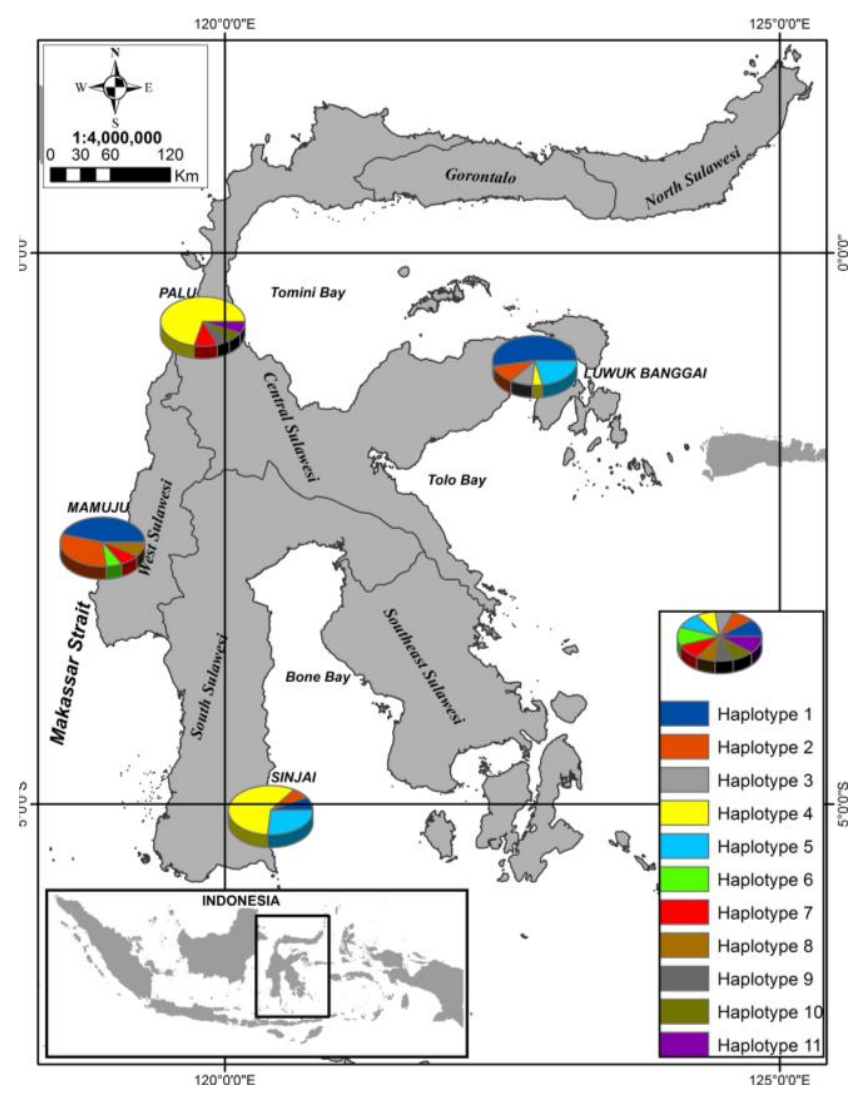

Figure 3. Haplotype map for Lobophyllia corymbosa. Pie graphs indicate haplotypic composition of each location/population

Table 2. Haplotype information each site defined

\begin{tabular}{lccc}
\hline Site & $\begin{array}{c}\text { Haplotype } \\
(\boldsymbol{h})\end{array}$ & $\begin{array}{c}\text { Haplotype } \\
\text { diversity } \\
(\text { Hd) }\end{array}$ & $\begin{array}{c}\text { Nucleotide } \\
\text { diversity }\end{array}$ \\
\hline Luwuk, Banggai & 4 & 0.554 & 0.006 \\
Sinjai & 4 & 0.600 & 0.005 \\
Mamuju & 5 & 0.730 & 0.008 \\
Palu & 6 & 0.652 & 0.005 \\
\hline
\end{tabular}

Table 3. Genetic structure analyses were conducted using AMOVA in Arlequin

\begin{tabular}{llccc}
\hline $\begin{array}{l}\text { Source of } \\
\text { variation }\end{array}$ & d.f & $\begin{array}{c}\text { Sum of } \\
\text { squares }\end{array}$ & $\begin{array}{c}\text { Variance } \\
\text { components }\end{array}$ & $\begin{array}{c}\text { Percentage } \\
\text { of variance }\end{array}$ \\
\hline $\begin{array}{l}\text { Among } \\
\text { population }\end{array}$ & 3 & 66.270 & $1.31150 \mathrm{Va}$ & 49.24 \\
$\begin{array}{l}\text { Within } \\
\text { population }\end{array}$ & 60 & 81.105 & $1.35176 \mathrm{Vb}$ & 50.76 \\
$\begin{array}{l}\text { Total } \\
\text { Fixation } \\
\text { index }\end{array}$ & 63 & & 2.63326 & \\
\hline
\end{tabular}

The distribution of haplotypes within each population was similar. Luwuk Banggai and Sinjai had four haplotypes for each site, while Mamuju has five haplotypes and the higher one from Palu with six haplotypes. The haplotype diversity (Hd) depended on the number of haplotypes were found, in populations with a relatively high number of haplotypes (h), i.e. Palu and Mamuju, the Hd values were 0.652 and 0.730 respectively, while Luwuk Banggai and Sinjai had lowest Hd values (0.553 and 0.600, respectively). To investigate population structure, pairwise Fst-values were estimated through an Analyses Molecular Variance ver. 3. 5.2.2 (AMOVA) (Excoffier et al. 2005), yielding a value of 0.492 (Table 3 ), indicating a moderate level of connection.

\section{Discussion}

Generally, in a region, the population has a close kinship value if it is in the same line, but this study found unusual connectivity patterns. Investigation of genetic connectivity information in the same species ( $L$. corymbosa) for four sites on a geographical basis visible enough to have a close relationship, but the results obtained did not show a harmonised congruent. The previous study by Cho and Shank (2010) presented the result which had connectivity pattern. It was not connected to Ophiroid species in Northern Atlantic even though the place geographically was not in an isolated area. Also, studied by Timm et al. (2017) in Spermonde Archipelago of Indonesia described the genetic information of coral population structures. It found that genetic flows were limited to their research sites although geographically still on a small scale, it was assumed that high recruitment in the area and weak currents also become a limitation in the distribution of gene material. While on a large extent, they found the closeness was close enough, this was also what happened in this study.

Location of Sulawesi in the central of Indonesia received a robust current flow from the Pacific Ocean to the Indian Ocean, where the vector flew towards the West and East waters of Sulawesi (Gordon and Fine 1996), allowing for a close genetic distance which occurred in both populations (Mamuju and Luwuk Banggai). Moreover, the $L$. corymbosa as a coral with a broadcast spawning reproduction type (Richmond and Hunter 1990) meaning that they had a more extended time period on the water column until settlement time to a suitable substrate making the species expected to perform "stepping stone" on islands or areas far from "home" to allow for the spread of coral larvae far enough. Meanwhile, the distance along the coastline from Palu to Mamuju ranged from $248 \mathrm{~km}$, not strong enough connection seen between these two populations, although both were quite close. The role of the current mentioned earlier was quite influential, especially the current of the Makassar Strait which directly traversed to the two populations, thus allowing the genes flew that form and became a barrier to the population. On the contrary, the genetic flow formed between Sinjai and Palu looked quite close even though it was about $856 \mathrm{~km}$ away. This also occurred in connectivity research on Acropora cervicornis in Florida. The results showed that although the Florida and Bahamas area had proximity $(200 \mathrm{~km})$ reasonably, no significant genetic relationship existed between the two populations (Hemond and Vollmer 2010). It was also mentioned in Wood et al. (2014), to simulate 
the spread of coral larvae, which indeed most coral larvae would settle not far from where they originated. However, some would travel beyond the usual $9,000 \mathrm{~km}$, thus making the potential for the larvae to navigate the various ocean basins until the time would arrive at a place that suited their habitat. However, it all depended on several factors which supported such oceanographic conditions which might also affect the gene flow patterns (Rogers 1994; Botsford et al. 2009; Clark et al. 2010; Shank 2010).

The presence of unexpected patterns formed in $L$. corymbosa in some locations in Sulawesi waters was also supported by data obtained from genetic diversity levels of haplotypes, diversity of haplotypes and nucleotide diversity (Table 2). The data also indicated that gene flow was distributed in each population was subject to limitations (Kochzius dan Nuryanto 2008). The habitat of $L$. corymbosa generally located in shallow waters in 4 research sites. Usually, the condition of all sites was less favourable for coral habitats. It could also be a trigger to the low or high flow of genes which occurred locally or regionally (Chiu et al. 2013). Based on the geographical area of Sulawesi waters, Luwuk Banggai, which located farther from the other three locations had its uniqueness over the type of the formed haplotype (Figure 3). There were similar studies to Neotrygon kuhlii species. There were six different lineages of this type, which were affected by the habitat and current conditions (Arlyza and Borsa 2010). It was considering that Luwuk Banggai location was quite "isolated" from the western region of Sulawesi. However, due to its current role, the population of $L$. corymbosa in that location could form a large connectivity group to the population in Mamuju (Figure 2). It was also increasingly supported by the previous study that geographical and oceanographic factors did influence the larval dispersal (Raynal et al. 2014).

Our results confirmed that a genetic approach could be used to investigate and identify patterns of dispersal, migration, and connectivity of an organism, especially in coral larvae both in inter- and intra-population. Connectivity formed at a location was closely related to genetic variation. A genetic variation which was formed indicated the ability of an organism to adapt to the conditions where it was located. As well as the genetic material from an area belonged to or distributed into a new environment would form a piece of different genetic information. Therefore, gene variations might provide information on the migrating pathways of coral larvae during the spawning season (Beardmore 1983). Environment condition has a vital role in maintaining the genetic susceptibility to an organism and would also preserve the biodiversity of Indonesia because genetic was the most basic and even smallest level of biodiversity for conservation. The implementation of genetic approach was beneficial to see the potential of habitats which would lead to the design of marine conservation or species management. This research also justified that in a broad ecosystem, it was possible to avoid the same pattern. The pattern of incongruent formed in a region could be unique to a species and its habitat.

\section{ACKNOWLEDGEMENTS}

The authors would like to express gratitude for the Master Program of Education Leading to Doctoral Degree for Excellent Graduates (PMDSU) Scholarship given by The Ministry of Research, Technology, and Higher Education with grant number SP DIPA042.06.1.401516/2018, Samsul Basri G. Karepesina and Mustono which provided the assistance to collect the samples in the field and also to the Biodiversitas Indonesia (BIONESIA) for providing facilities needed in molecular sample work.

\section{REFERENCES}

Arlyza I, Borsa P. 2008. Geographic structure of masked stingray in the Indo-Malay-Papua Archipelago. Conser Biol. 22 (5): 1255-1266.

Barber PH, Boyce SL. 2006. Estimating diversity of Indo-Pacific Coral Reef Stomatopods through DNA barcoding of Stomatopod larvae. Proc R Soc B Biol Sci 273 (1597): 2053-2061. DOI: 10.1098/rspb.2006.3540

Barber PH, Cheng S, Erdmann M, Tenggardjaja K. 2011. Evolution and conservation of marine biodiversity in The Coral Triangle: Insights from Stomatopod crustacea. Crustacean Issues19: 129-156.

Barber PH, Moosa MK, Palumbi SR. 2002. Rapid recovery of genetic diversity of Stomatopod populations on Krakatau: Temporal and spatial scales of marine larval dispersal. Proc R Soc B Biol Sci 269 (1500): 1591-1597. DOI: 10.1098/rspb.2002.2026

Barber PH, Palumbi SR, Erdmann MV, Moosa MK. 2000. Biogeography. A Marine Wallace's line. Nature 406 (6797): 692-693.

Beardmore JA. 1983. Extinction, survival, and genetic variation. In genetics and conservation. Schonewald-cox, CMS, Chambers, M, Macbryde B, Thomas WL (ed.). The Benjamin/Cummings Publishing Company, Inc., London.

Bellwood DR, Meyer CP. 2009. Searching for heat in a marine biodiversity hotspot. J Biogeogr 36: 569-576.

Botsford LW, White JW, Coffroth MA, Paris CB, Planes S, Shearer TL, Thorrold SR, Jones GP. 2009. Connectivity and resilience of coral reef metapopulations in marine protected areas: Matching empirical efforts to predictive needs. Coral Reefs. 28: 327-337. DOI: 10.1007/s00338-009-0466-z

Burke L, Elizabeth S, Mark S. 2002. Terumbu karang yang terancam di Asia Tenggara. World Resources Institute, USA. [Indonesia].

Carpenter KE, Barber PH, Crandall ED, et al. 2011. Comparative phylogeography of the coral triangle and implications for marine management. J Mar Biol 14: 396982. DOI: 10.1155/2011/396982

Cesar H, Burke, Pet-Soede L. 2003. The Economics of Worldwide Coral Reef Degradation. Cesar Environmental Economics Consulting (CEEC), Nederlands.

Chiu Y, Bor H, Tan M, Lin H, Jean C. 2013. Phylogeography and genetic differentiation among populations of the moon turban snail Lunella granulata gmelin, 1791 (Gastropoda: Turbinidae). Intl J Mol Sci 14: 9062-9079. DOI: 10.3390/ijms14059062

Cho W, Shank MT. 2010. Incongruent patterns of genetic connectivity among four Ophiuroid species with differing coral host specificity on North Atlantic seamounts. Mar Ecol. DOI: 10.1111/j.14390485.2010.00395.x

Clark MR, Rowden RT, Schlacher T, Williams A, Consalvey M, Stocks KI, Rogers AD, O'Hara TD. et al. 2010. The ecology of Seamounts: Structure, function, and human impacts. Ann Rev Mar Sci 2: 253-278. DOI: 10.1146/annurev-marine-120308-081109

Coexploration. 2017. Life cycle story. http: //www.coexploration.org. [online]

Crandall ED, Taffel JR, Barber PH. 2010. High gene flow due to pelagic larval dispersal among South Pacific Archipelagos in two Amphidromous Gastropods (Neritomorpha: Neritidae). Heredity 104 (6): 563-572.

DeBoer TS, Barber PH. 2010. Isolation and characterization of 9 polymorphic microsatellite markers for the endangered boring giant clam (Tridacna crocea), cross-priming testing in three other 
Tridacnid species. Conserv Genet Resour. 2: 353-356. DOI: 10.1007/s12686-010-9249-7

Excoffier L, Laval G, Schneider S. 2005. Arlequin ver. 3.0: An integrated software package for population genetics data analysis. Evolutionary Bioinformatics Online 1: 47-50.

Fukami H, Budd A, Paulay G, sole-Cava A, Chen CA, Iwao K, Kwlton N. 2004. Conventional taxonomy obscurres deep divergence between Pacific and Atlantic corals. Nature 427: 832: 834. DOI: 10.1038/nature02339

Gordon AL, Fine RA. 1996. Pathways of water between the Pacific and Indian Oceans in the Indonesian seas. Nature. 379: 146-149. DOI: $10.1038 / 379146 \mathrm{a} 0$

Hedgecock D, Barber PH, Edmands S. 2007. Genetic approaches to measuring connectivity. Oceanography 20: 70-79.

Hemond EM, Vollmer SV. 2010. Genetic diversity and connectivity in the Threatened Staghorn coral (Acropora cervicornis) in Florida. PLoS ONE 5 (1): e8652. DOI: 10.1371/journal.pone.0008652

Huang D, Licuanana WY, Baird AH, Fukami H. 2011. Cleaning up the 'Bigmessidae': Molecular phylogeny of scleractinian corals from Faviidae, Merulinidae, Pectiniidae and Trachyphylliidae. BMC Evol Biol 471-2148/11/3. DOI: 10.1186/1471-2148-11-37

Kimura M. 1980. A simple method for estimating evolutionary rate of base substitutions through comparative studies of nucleotide sequences. J Mol Evol 16: 111-120

Kochzius M, Nuryanto A. 2008. Strong genetic population structure in the boring giant clam, Tridacna crocea, across the Indo-Malay Archipelago: Implications related to evolutionary processes and connectivity. Mol Ecol. 17: 3775-3787. DOI: 10.1111/j.1365294X.2008.03803.x

Kool J, Moilanen A, Treml E. 2013. Population connectivity: Recent advances and new perspectives. Landsc Ecol 28: 165-185.

Kortschak RD, Samuel G, Saint R, Miller DJ. 2003. EST analysis of the cnidarian Acropora millepora reveals extensive gene loss and rapid sequence divergence in the model invertebrates. Curr Biol 13: 21902195. DOI: $10.1016 /$ j.cub.2003.11.030

Librado P, Rozas J. 2009. DnaSP v5: A software for comprehensive analysis of DNA polymorphism data bioinformatics. Bioinformatics 25: 1451-1452. DOI: 10.1093/bioinformatics/btp187.

Raynal J, Crandall E, Barber PH, Mahardika G, Ablan L, Carmen M, Carpenter EK. 2014. Basin isolation and oceanographic features influencing lineage divergence in the humbug damselfish (Dascyllus aruanus) in The Coral Triangle. Bull Mar Sci 90: 513-532. DOI 10.5343/bms.2013.1017.http: //dx.doi.org/10.5343/bms.2013.1017
Richmond R, Hunter C. 1990. Reproduction and recruitment of corals: Comparisons among the Caribbean, the tropical pacific, and the Red Sea. Mar Ecol Prog Ser 60: 185-203. DOI: 10.3354/meps060185

Roberts CM, McClean CJ, Veron JEN, Hawkins JP, Allen GR, McAllister DE, Mittermeier CG, Schueler FW, et al. 2002. Marine biodiversity hotspots and conservation priorities for tropical reefs. Science 295: 1280-1284.

Rogers AD. 1994. The biology of Seamounts. Adv Mar Biol 30: 305350.DOI: $10.1016 / \mathrm{S} 0065-2881$ (08)60065-6

Shank TM. 2010. Seamounts: Deep-Ocean laboratories of faunal connectivity, evolution, and endemism. Oceanography 23: 108-122. DOI: $10.5670 /$ oceanog.2010.65

Starger CJ, Barber PH, Ambariyanto, Baker AC. 2010. The recovery of coral genetic diversity in the Sunda Strait following the 1883 eruption of Krakatau. Coral Reefs 29: 547. DOI: 10.1007/s00338-010-0609-2

Tamura K, Nei M. 1993. Estimation of the number of nucleotide substitutions in the control region of mitochondrial DNA in humans and chimpanzees. Mol Biol Evol 10: 512-526.

Tamura K. Stecher G, Peterson D, Filipski A, Kumar S. 2013. MEGA6: Molecular version 6.0. Mol Biol Evol 30: 2725-2729.

Timm J, Kochzius M, Madduppa HH, Neuhaus AI, Dohna T. 2017. Small scale genetic population structure of coral reef organisms in Spermonde Archipelago, Indonesia. Front Mar Sci 4: 294. DOI: 10.3389/fmars.2017.00294

Treml E, Roberts J, Chao Y, Halpin PN, Possingham H, Riginos C. 2012. Reproductive output and duration of the pelagic larval stage determine seascape-wide connectivity of marine populations Integr Comp Biol 52 (4): 525-537.

Turak E, Sheppard C, Wood E. 2014. Lobophyllia corymbosa. [online] The IUCN Red List of Threatened Species 2014: e.T133551A54282200. http: DOI: 10.2305/IUCN.UK.20141.RLTS.T133551A54282200.en

Van der Ven RM, Triest L, De Ryck DJR, Mwaura JM, Mohammed MS, Kochzius M. 2016. Population genetic structure of the stony coral Acropora tenuis shows high but variable connectivity in East Africa. J Biogeogr 43: 510-519. DOI: 10.1111/jbi.12643

Vollmer SV, Palumbi SR. 2007. Restricted gene flow in the Caribbean staghorn coral Acropora cervicornis: Implications for the recovery for endangered reefs. J Heredity 98 (1): 40-50. DOI: $10.1093 /$ jhered/es1057

Wood S, Paris CB, Ridgwell A, Hendy EJ. 2014. Modelling dispersal and connectivity of broadcast spawning corals at the global scale. Global Ecol Biogeogr 23: 1-11. DOI: 10.1111/geb.12101 